\title{
Marcelo Coelho
}

\section{Como você pensa a relação entre o tempo literá- rio e o tempo histórico?}

Prefiro pensar na relação entre o tempo literário e a situação histórica. Nos anos 1980 e 1990 a sensação do escritor foi, predominantemente, a de que não se estava nem às vésperas de uma redenção, nem de um apocalipse; de alguma forma, a literatura não tinha como contar com os ventos "a favor", associados a uma ideia de progresso, nem com os ventos "contra", associados a uma crise geral da civilização. Nesta situação, que parece desestimular qualquer filosofia da história, creio que o tempo literário deixa de se medir como reação coletiva, organizada esteticamente em movimentos (celebração-conflito com a modernidade, nos anos 1920, retorno à ordem, nos anos 1940-1950, engajamento, desbunde, mais tarde). O resultado tem sido a predominância do testemunho (seja a autobiografia confessional, sejam os relatos de sobrevivência na periferia) e da biografia jornalístico-literária, na qual a visão da personagem histórica é a solução encontrada para tomar a história como objeto, e não mais como elemento substancial, inscrito na matéria da obra literária. Desse modo, por vários lados, a literatura se aproxima do jornalismo, à medida que tem com a história não uma relação visceral, e sim uma relação externa: a literatura passa a ver a história, presente ou passada, como seu objeto, não como seu elemento.
Quais procedimentos sua obra adota diante de um mundo em que predominam a ação econômica e a espetacularização da arte?

Há evidentemente uma preocupação mercadológica maior nos escritores de hoje, o que reflete a sua progressiva profissionalização. De minha parte, prefiro falar menos em espetacularização da arte e mais em indústria cultural. Diante dessa indústria cultural, creio que passou o momento de reagir parodicamente aos procedimentos voltados para o público de massa, ou de ignorá-los olimpicamente. A indústria cultural tornou-se uma espécie de "segunda natureza" para o escritor, mesmo o mais elitista; penso em relacionar-me com ela do mesmo modo com que os românticos se relacionavam com a natureza e a cultura popular: tomando-a como ponto de partida para dizer o que ela não diz; para salvá-la, digamos assim, de sua própria condição degradada e miserável.

\section{Qual reflexão sua obra produz sobre a tradição literária brasileira?}

Vejo-me numa relação de forte ojeriza a muito do que foi produzido nos últimos trinta ou quarenta anos, que sintetizo nos nomes de Rubem Fonseca e dos concretos. Sem condição de me inspirar nas obras-primas do ciclo nordestino ou de Guimarães Rosa, e admirando Machado de Assis a certa distância, acabo achando que minha tradição, no que diz respeito à literatura brasileira, é mais a ensaística que a ficcional. Sou também tributário de uma tradição mais beletrística, a dos que privilegiavam o tour de force estilístico e ornamental, como Euclides da Cunha. Em todo caso, sinto-me um pouco à margem, no vestíbulo, da própria literatura enquanto tal, pela qual incursiono com pouca frequência. 


\section{Como você pensa a forma literária?}

Penso a forma literária muito de acordo com a linguagem da música clássica: gosto de preparar dissonâncias e resoluções numa frase, num parágrafo, numa página; de retomar os temas da exposição, desenvolvendo-os; de recorrer a coisas como ritardando, accelerando... A consequência é uma forte incapacidade para conceber conforme um plano narrativo aquilo que escrevo. É, digamos, uma escrita mais abstrata.

Marcelo Coelho (1959) colabora semanalmente no caderno llustrada do jornal Folha de São Paulo desde 1991. Como ficcionista, publicou Patópolis (lluminuras, 2010), Noturno (lluminuras, 1994) e Jantando com Melvin (Imago, 1997). É autor dos livros infantis $A$ professora de desenho e outras histórias (Companhia das Letrinhas, 1995) e Minhas férias (Companhia das Letrinhas, 1999). Na área de não ficção, escreveu Crítica cultural: teoria e prática (Publifolha, 2006) e Tempo medido (Publifolha, 2007). 